\title{
Fluid flow modulates the expression of genes involved in the Wnt signaling pathway in osteoblasts in 3D culture conditions
}

\author{
YUAN-YUAN JIA ${ }^{1,2^{*}}$, FENG LI ${ }^{4 *}$, NING GENG ${ }^{1,3}$, PING GONG $^{1,2}$, SHI-JIE HUANG ${ }^{1,2}$, \\ LING-XIAN MENG ${ }^{1,2}$, JING LAN ${ }^{1}$ and YU BAN ${ }^{1,2}$
}

${ }^{1}$ State Key Laboratory of Oral Diseases, Departments of ${ }^{2}$ Oral Implant Center and ${ }^{3}$ Oral Histology and Pathology, West China School of Stomatology, Sichuan University, Chengdu, Sichuan 610041; ${ }^{4}$ Department of Stomatology, The People's Hospital of Deyang City, Deyang, Sichuan 618000, P.R. China

Received October 29, 2013; Accepted February 26, 2014

DOI: $10.3892 / \mathrm{ijmm} .2014 .1694$

\begin{abstract}
The balance between osteoclastic bone resorption and osteoblastic bone formation maintains bone mass, while mechanical loads stimulate bone formation and suppress resorption. The molecular mechanisms responsible for this process have not yet been fully elucidated. In the present study, we assessed whether mechanical stimulation by pulsating fluid flow (PFF) leads to functional Wnt production and affects the function of osteoblasts. ROS17/2.8 osteoblasts were submitted to $1-4 \mathrm{~h}$ PFF $(0.8 \mathrm{~Pa})$ by three-dimensional (3D) cell culture system with fluid flow. PFF upregulated the gene expression levels of adenomatous polyposis coli, alkaline phosphatase, low density lipoprotein receptor-related protein 5 (LRP5), Wnt3a and $\beta$-catenin [catenin beta 1 (CTNNB1)] in all the groups of osteoblasts. Our results suggest that mechanical stimulation by PFF induces the differentiation of osteoblasts and the activation of the Wnt/ $\beta$-catenin signaling pathway in a $3 \mathrm{D}$ cell culture system. Furthermore, mechanical stress plays an important role in the Wnt/ $\beta$-catenin signaling pathway and is involved in bone formation.
\end{abstract}

\section{Introduction}

Bone mass in adults is maintained locally by the balance between osteoclastic bone resorption and osteoblastic bone formation, each of which is subject to various factors aimed at fulfilling bone function. This function, termed remodeling, is influenced by a number of factors, including growth factors, systemic hormones and the mechanical environment (1).

Correspondence to: Dr Yu Ban, Department of Oral Implant Center, West China School of Stomatology, Sichuan University, 14 3rd Section Renmin Nan Road, Chengdu, Sichuan 610041, P.R. China

E-mail: banyuby@163.com

*Contributed equally

Key words: osteoblasts, fluid shear stress, Wnt/ $\beta$-catenin, scaffolds, gene expression
Mechanical loads affect the balance of bone formation and resorption. Mechanical stimulation is recognized as a major mediator of both osteogenic and angiogenic activities in bone. An appropriate function of stress is beneficial to the normal metabolism of bone tissue and the formation of new bone. Normal bone tissue activity would normally result in osteoporosis and bone resorption, if not for proper stimulation. Thus, stress stimulation plays an important role in remodeling (2).

When mechanical loads stimulate bone tissue, the interstitial fluid flow has an impact on the osteoblast, which is in the porous bone tissue. By fluid shear stress stimulation, the osteoblast transforms a mechanical signal to a biochemical signal, and then regulates the formation and resorption of bone (3). Increased mechanical loads stimulate bone formation and suppress resorption, whereas unloading has the opposite effect (4). Wnts are involved in this process.

Wnts are a large family of 19 secreted carbohydrate- and lipid-modified polypeptides that mediate important biological processes (5). The $\mathrm{Wnt} / \beta$-catenin pathway is one of the Wnt signaling pathways, and it is also a main factor in the mediation of bone remodeling. The $\mathrm{Wnt} / \beta$-catenin signaling pathway facilitates the formation of new bone by inducing the differentiation of pluripotent mesenchymal cells into osteoblast progenitors, becoming osteoblasts, thus maintaining the precursor status of these osteoprogenitors, inhibiting osteoblast apoptosis, and promoting osteoblast proliferation and differentiation $(6,7)$.

As both mechanical stimulation and the Wnt pathway are critical anabolic signaling factors affecting bone formation, the demonstration of stress regulation of Wnt expression in osteoblasts may provide new insight into the role of the functional communication between stress and Wnt signaling pathways that affect bone formation. In the present study, we assessed whether mechanical stimulation by pulsating fluid flow (PFF) leads to functional Wnt production.

Historically, two-dimensional (2D) cultures in vitro have played a key role in the study of bone mechanobiology; however, 2D experiments are performed on flat surfaces, which do not reflect the environment of three-dimensional (3D) architecture in vivo. Studies have proven that 2D models do not always accurately represent what will occur under 3D culture conditions (8-11). 
Barron et al (12) demonstrated that a 3D grafting structure and in vitro cultures under dynamic conditions provide critical information to defining the fundamental biochemical and biomechanical responses of bone cells. Therefore, in a previous study, we designed and fabricated a 3D fluid flow cell culture system, which can load shear stress on cells that are cultured on scaffolds (13).

Therefore, the aim of this study was to evaluate whether mechanical stimulation by means of PFF affects the function of osteoblasts and Wnt production in osteoblasts.

\section{Materials and methods}

Cell culture. The osteoblast-like rat osteosarcoma cells, ROS17/2.8, between passages 20 and 26 were cultured in Dulbecco's modified Eagle's medium (DMEM) - low-glucose medium with $10 \%$ fetal bovine serum (FBS) and $1 \%$ penicillin/ streptomycin (all from Gibco-Invitrogen, Carlsbad, CA, USA), and were set in a $37^{\circ} \mathrm{C}$ incubator with $5 \%$ carbon dioxide and moisture.

Scaffolds. Partially deproteinized bone (PDPB; Yantai Zhenghai Biology Technology Co., Ltd., China) was used as a scaffold for osteoblasts. The scaffolds were round, $10 \mathrm{~mm}$ in diameter and $2 \mathrm{~mm}$ in thickness with an average porosity of $79 \pm 1.2 \%$ and a pore diameter of $300-500 \mu \mathrm{m}$ (Fig. 1A).

Cell seeding. The cells were harvested (trypsinized and resuspended in culture medium) after reaching $80 \%$ confluency. Subsequently, 2,000,000 cells in $100 \mu 1$ medium were seeded onto each $3 \mathrm{D}$ calcium phosphate scaffold in 24-well plates (2,000,000 cells/scaffold) (Fig. 1B-a). After 2 h, 2 ml medium were added to each well and the cells were allowed to attach for $24 \mathrm{~h}$ in a $37^{\circ} \mathrm{C}$ incubator (Fig. 1B-b).

Mechanical loading in 3D. The 3D fluid flow cell culture system consists of 8 flow chambers, platinum-cured silicon tubing, reservoirs, a gas filter and a pump (Tianjin Xieda Weiye Electron Co., Ltd., Tianjin, China) (Fig. 2A). Scaffold/ cell constructs were then placed into each chamber, which was made of $2 \mathrm{ml}$ glass syringes. The scaffolds were fixed by a cut radial plunger (Fig. 2B).

Experimental design. The PFFs were generated by a roller pump, and the value of $0.8 \mathrm{~Pa}$ used for shear stress was based on the outcome of the theoretical model proposed in the study by Weinbaum et al (20). There were 4 loading treatments. Teh scaffolds were thus divided into 4 groups: group A remained incubated at $37^{\circ} \mathrm{C}$ with $5 \% \quad \mathrm{CO}_{2}$ for the duration of the experiment. Groups B-D were placed in their chambers and connected to the flow circuit. Loading occurred immediately after the 3D fluid flow cell culture system was connected and continued for $1 \mathrm{~h}$ and statically incubated for $23 \mathrm{~h}$ for group B, $2 \mathrm{~h}$ and statically incubated for $22 \mathrm{~h}$ for group $\mathrm{C}$, and $4 \mathrm{~h}$ and statically incubated for $20 \mathrm{~h}$ for group D. All samples were removed for analysis at $24 \mathrm{~h}$.

Scanning electron microscopy (SEM). For SEM, the samples were rinsed twice with calcium-free phosphate-buffered saline (PBS) and fixed in $2.5 \%$ glutaraldehyde at $4^{\circ} \mathrm{C}$ overnight. The samples were then dehydrated in a graded series of ethanol (30, 50, 70, 85, 90 and 100\%), dried with tetramethylsilane, sputtercoated with gold and examined using an Inspect $F$ scanning electron microscope (FEI Inspect F, The Netherlands) at an acceleration voltage of $15 \mathrm{kV}$.

$R N A$ isolation and $q R T-P C R$. The scaffolds was transferred into a cryotube and immediately shock-frozen and pulverized in liquid nitrogen. Total RNA was extracted using TRIzol reagent (Invitrogen) and frozen at $-70^{\circ} \mathrm{C}$ for subsequent RNA isolation.

cDNA synthesis was performed using $0.5-1 \mathrm{mg}$ of total RNA in a $20-\mu 1$ reaction mixture consisting of 5 units of PrimeScript $^{\mathrm{TM}} \mathrm{RT}$ reagent kit (Takara Bio, Inc., Shiga, Japan) at $37^{\circ} \mathrm{C}$ for $15 \mathrm{~min}$, and terminated by heating at $85^{\circ} \mathrm{C}$ for $5 \mathrm{sec}$ followed by cooling at $4^{\circ} \mathrm{C}$ in a thermal cycler (i-Cycler; Bio-Rad, Hercules, CA, USA). The cDNA was then used for real-time PCR for the genes of interest and glyceraldehyde phosphate dehydrogenase (GAPDH) was used as a housekeeping gene.

Real-time PCR was performed in $20 \mu \mathrm{l}$ total volume for each sample, containing $2 \mu \mathrm{l}$ cDNA template, $10 \mu \mathrm{l} \mathrm{SYBR}{ }^{\circledR}$ Premix Ex Taq ${ }^{\mathrm{TM}}$ (Takara Bio, Inc.), $0.8 \mu 1$ each of forward and reverse primers, and $0.4 \mu 1$ ROX Reference Dye with the 7300 realtime PCR system. The primers of alkaline phosphatase (ALP), low density lipoprotein receptor-related protein 5 (LRP5), catenin beta 1 [(CTNNB1), also known as $\beta$-catenin], Wnt3A, adenomatous polyposis coli (APC) and GAPDH (synthesized by Takara Biotechnology Co. Ltd., Dalian, China) are listed in Table I. Cycling conditions were as follows: $95^{\circ} \mathrm{C}$ for $30 \mathrm{sec}$, followed by 40 cycles of $95^{\circ} \mathrm{C}$ for $5 \mathrm{sec}$ and $60^{\circ} \mathrm{C}$ for $31 \mathrm{sec}$, then $95^{\circ} \mathrm{C}$ for $15 \mathrm{sec}$ and $60^{\circ} \mathrm{C}$ for $31 \mathrm{sec}$, and $95^{\circ} \mathrm{C}$ for $15 \mathrm{sec}$.

Statistical analysis. All experiments were run 3 times with triplicate samples. Significant differences were determined by one-way analysis of variance (ANOVA) followed by a Newman-Keuls post hoc test, and all data are expressed as the means \pm standard deviation (SD). In all the analyses, values of $\mathrm{P}<0.05$ were considered to indicate statistically significant differences. All the data were analyzed using SPSS 13.0 software (SPSS Inc., Chicago, IL. USA).

\section{Results}

SEM: PFF stimulates osteoblasts that are larger, more spread out and thicker extracellularly, in a 3D fluid flow cell culture system. SEM was used to visualize the scaffold/cell constructs in order to assess cell morphology (x300, x600 and x1,200 magnification). Fig. 3A shows microscopic images of the scaffold/cell constructs after $24 \mathrm{~h}$ static culture, while Fig. 3B-D shows microscopic images of group $\mathrm{B}$ (PFF for $1 \mathrm{~h}$ and statically incubated for $23 \mathrm{~h}$ ), group $\mathrm{C}$ (PFF for $2 \mathrm{~h}$ and statically incubated for $22 \mathrm{~h}$ ) and group D (PFF for $4 \mathrm{~h}$ and statically incubated for $20 \mathrm{~h}$ ). In the PFF culture, the cells were larger, more spread out, and appeared to be surrounded by thicker extracellular matrix constructs than the cells cultured under static conditions.

Fig. 3A shows the SEM view of the control group A, in which the osteoblasts covered most of the scaffold surface, had a long fusiform or polygon shape and were arranged in a disor- 

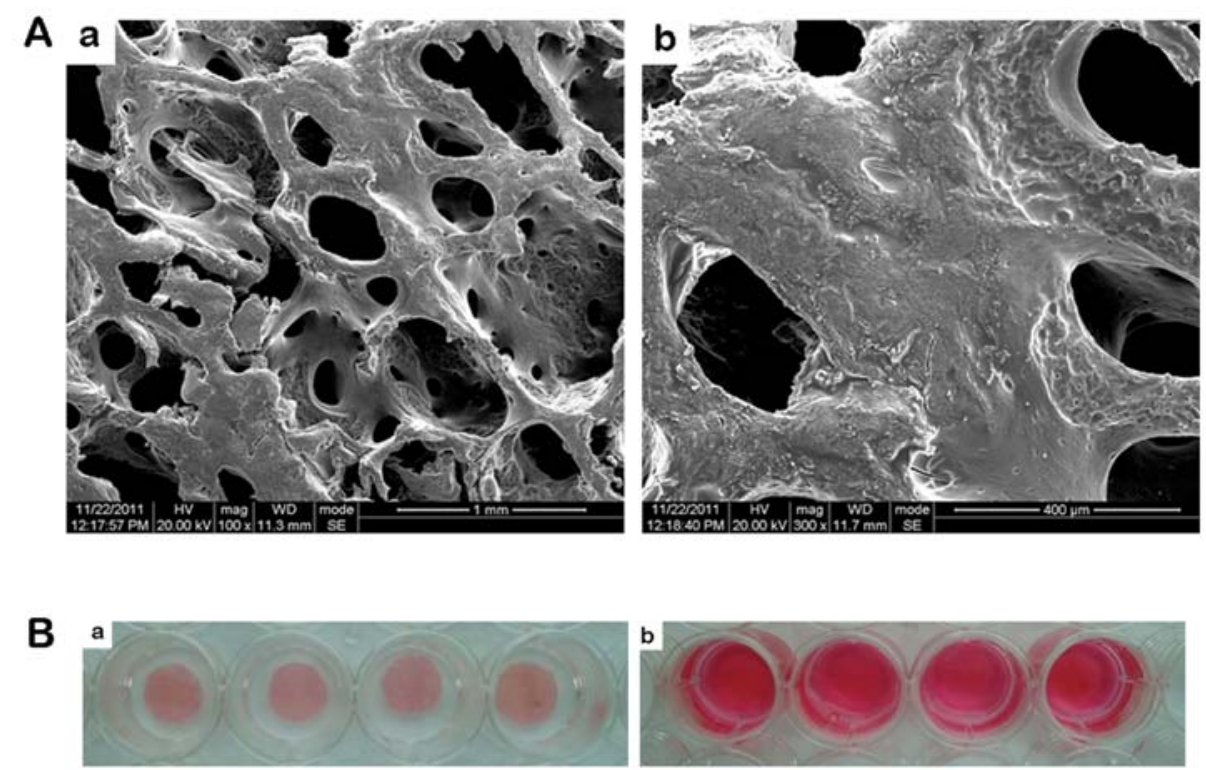

Figure 1. Scanning electron microscopy (SEM) images of the surface of the partially deproteinized bone (PDPB). (A) PDPB with an average porosity of $79 \pm 1.2 \%$ and a pore diameter of 300-500 $\mu \mathrm{m}$ (a, x100; b x300 magnification). (B) Scaffolds in 24-well plates were seeded with 2,000,000 cells in (a) 100 $\mu 1$ medium; (b) $2 \mathrm{ml}$ medium were added to each well $2 \mathrm{~h}$ later.

A

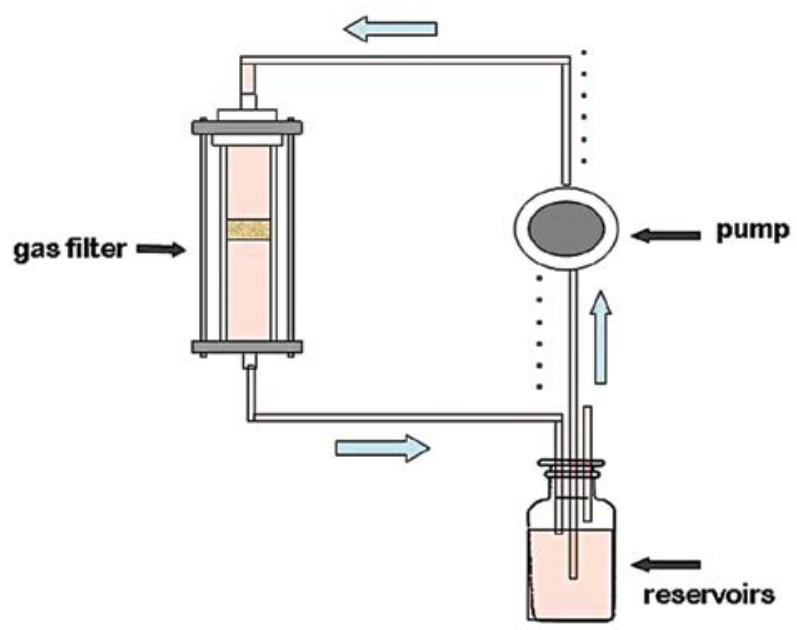

B
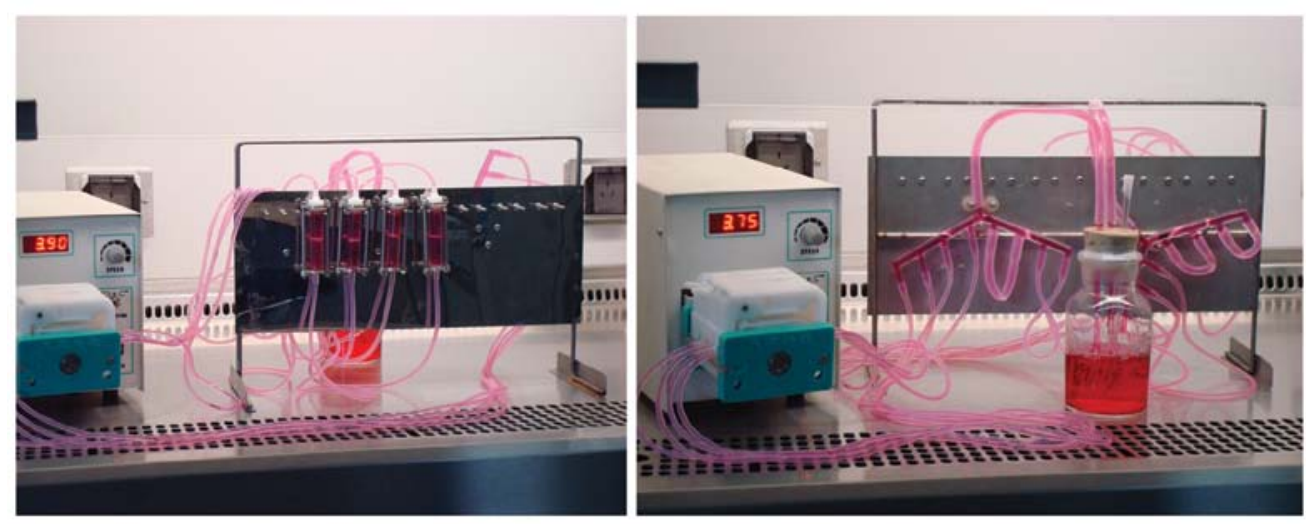

Figure 2. (A) Schematic representation of the chamber and fluid flow cell culture system. (B) Image of the flow perfusion bioreactor.

derly manner. Group B-D scaffolds were completely covered with osteoblasts and the cells were polygonal in shape. In some osteoblasts, many tiny synaptic adhesions had extended from the cells in the scaffolds, and the cells were gathered together more closely and were integrated. It could be seen the bigger and rougher cells that contained a large number of processes (needle-like structures), indicating osteoblasts with increased secretion. The cells were arrayed with obvious directionality, 
Table I. The base of primers for quantitative real-time RT-PCR.

\begin{tabular}{lllc}
\hline Genes & \multicolumn{1}{c}{ Left primer } & \multicolumn{1}{c}{ Right primer } & Product size (bp) \\
\hline GAPDH & TATGACTCTACCCACGGCAAGT & ATACTCAGCACCAGCATCACC & 138 \\
ALP & GACCCTGCCTTACCAACTCATT & GTGGAGACGCCCATACCATCT & 166 \\
APC & GAGTCAGCATCCAAAGGACTGA & GACTGGCGTACTAATGCAGGTCT & 140 \\
LRP5 & GAGTCAGCATCCAAAGGACTGA & CCAGGCTCACAGAACTCATCA & 116 \\
Wnt3a & ACGAGAGGATTGAGAGCGTCA & GATAAGGGTCTTTGAGCGAGTCC & 118 \\
CTNNB1 & GGGTCCTCTGTGAACTTGCTC & CTTGTAGTCCTGTGGCTTGTCC & 167 \\
\hline
\end{tabular}

GAPDH, glyceraldehyde phosphate dehydrogenase; ALP, alkaline phosphatase; APC, adenomatous polyposis coli; LRP5, low density lipoprotein receptor-related protein 5; CTNNB1, catenin beta 1 (also known as $\beta$-catenin).
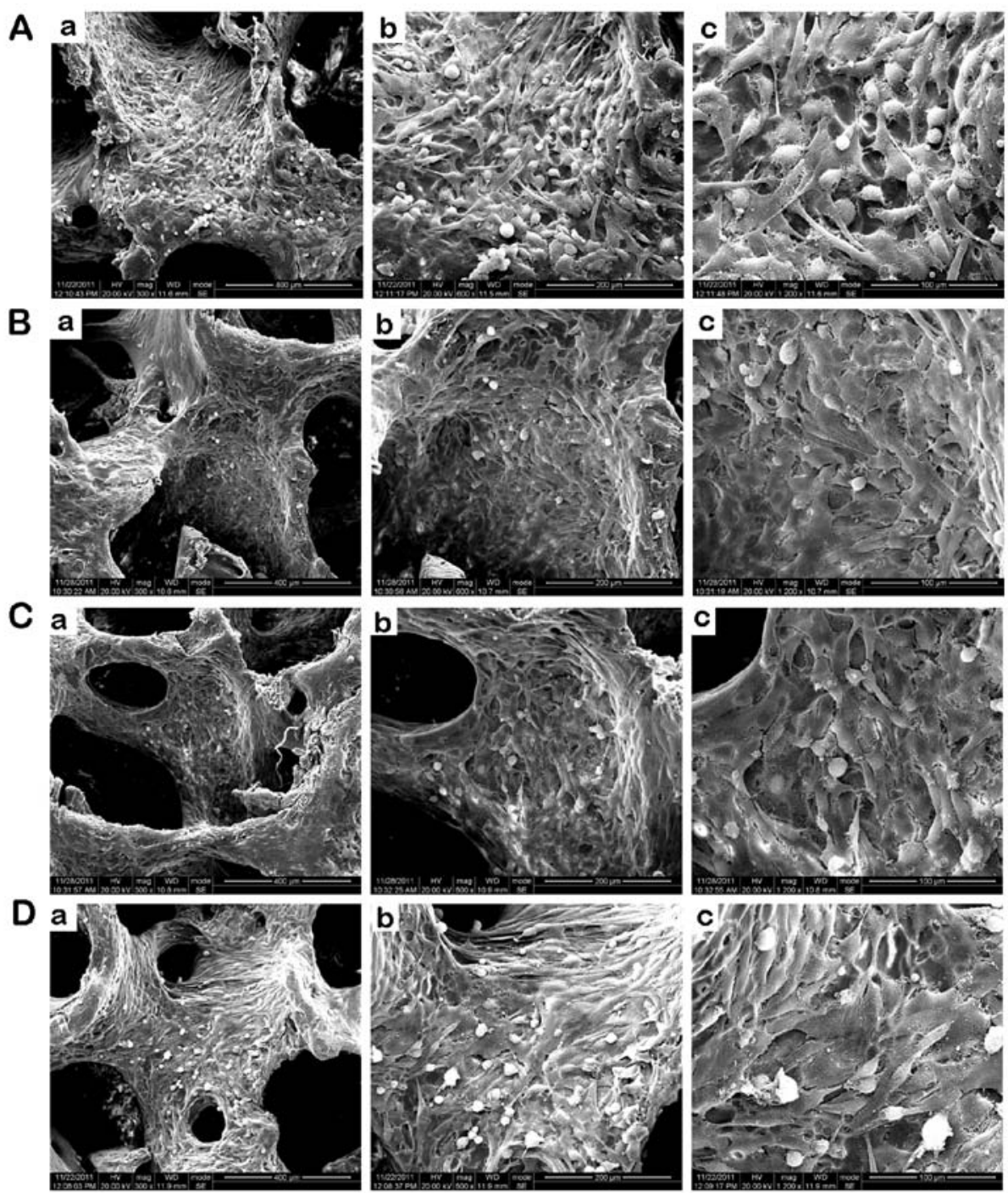

Figure 3. Scanning electron microscopy (SEM) images of the surface of the seeded scaffold after $24 \mathrm{~h}$. (A) Group A: kept under static culture conditions (a, x300; b, x600; c, x1200 magnification). (B) Group B: cells were subjected to pulsating fluid flow (PFF) for $1 \mathrm{~h}$ and statically incubated for $23 \mathrm{~h}$ (a, x300; b, x600; c, x1200 magnification). (C) Group C: cells subjected to PFF for $2 \mathrm{~h}$ and statically incubated for $22 \mathrm{~h}$ (a, x300; b, x600; c, x1200 magnification). (D) Group D: cells were subjected to PFF for $4 \mathrm{~h}$ and statically incubated for $20 \mathrm{~h}$ (a, x300; b, x600; c, x1200 magnification).

according to the direction of PFF. In group C, osteoblasts were covered with layers of some parts of the scaffolds, and the number of cells had increased. In group $\mathrm{D}$, the elongated osteoblasts in the shear direction were more apparent, the surface of cells became rougher, and some exfoliated cells were observed occasionally. In addition, a higher cell density and more extracellular matrix was observed as compared with the perfusion groups and the static culture group. 

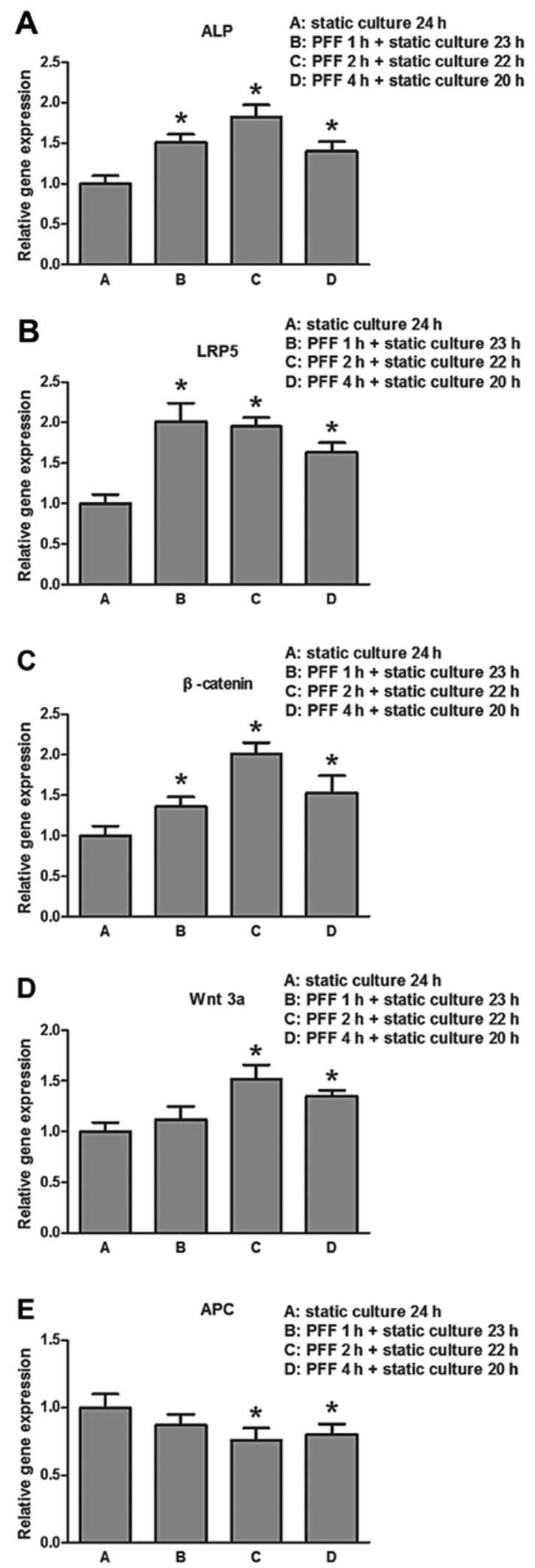

Figure 4. Effects of fluid shear stress on osteogenic differentiation marker genes in osteoblasts. (A) The mRNA expression level of alkaline phosphatase (ALP) was increased in the groups in which cells were induced with pulsating fluid flow (PFF). (B) The mRNA expression level of LRP5 was increased in groups in which cells were stimulated by PFF. (C) The mRNA expression level of $\beta$-catenin was increased in groups in which cells were stimulated by PFF. (D) The mRNA expression level of Wnt3A was increased in groups in which cells were stimulated by PFF. (E) The mRNA expression level of adenomatous polyposis coli (APC) was decreased in groups in which cells were stimulated by PFF. Error bars represent the means \pm standard deviation (SD); $\mathrm{n}=3$ experiments. Significant differences were set at ${ }^{*} \mathrm{P}<0.05$.
PCR: PFF upregulates the expression of osteogenic genes of osteoblasts and activates the Wnt/ $\beta$-catenin signaling pathway in the $3 D$ fluid flow cell culture system. We assessed whether $\mathrm{PFF}$ affects the expression of proteins related to osteogenesis, as well as genes involved in the canonical Wnt signaling pathway. The results revealed that PFF upregulated the expression of osteogenic genes in osteoblasts and activated the Wnt/ $\beta$ catenin signaling pathway. The mRNA expression of ALP significantly increased in the groups in which the cells were stimulated by PFF $(\mathrm{P}<0.05)($ Fig. 4A). LRP5, $\beta$-catenin and Wnt3A, the makers of the Wnt/ $\beta$-catenin signaling pathway, demonstrated an increased mRNA expression in the cells that were stimulated by PFF $(\mathrm{P}<0.05)($ Fig. $4 \mathrm{~B}$ and $\mathrm{C})$. However, as the negative regulator of the key protein in the $\mathrm{Wnt} / \beta$-catenin signaling pathway, the mRNA expression of APC was significantly decreased in all the PFF groups $(\mathrm{P}<0.05)$ (Fig. 4E).

\section{Discussion}

Bone is a dynamic tissue and is constantly under conditions of growth and remodelling. It adapts to both physiological and physical environments and undergoes continuous remodeling throughout life. Osteoblasts secrete new bone, by sensing and responding to mechanical stimulation via stress-generated fluid flow inside the canalicular-lacunar networks and trabecular spaces within bone tissue. Traditionally, 2D in vitro culture [such as the parallel plate flow chamber (PPFC)] (14) is a method normally used in the study of fluid shear stress. A number of studies have shown that the majority of adhered cells respond differently if cultured in 2D and 3D substrates (15-19). In comparison to 2D monolayer cultures, 3D culture system devices represent valuable tools for the establishment of physiologically oriented in vitro tissue models.

Previous studies have proven that the mechanical loading of bone engenders the movement of extracellular fluid through the bone lacunar-canalicular system. Such fluid flow may stimulate bone cells via streaming potentials, wall shear stress, or chemo-transport related effects. Biot's porous media theory has been used to relate whole bone stress to canalicular interstitial fluid flow past osteocytic processes (20). It was predicted that loading regimens engendering peak physiological strains will induce fluid-induced shear stresses of 0.8-3 Pa. Subsequently, Bakker et al (21) used PFF to generate fluid shear stress of 0.2-1 Pa.

In this study, a higher cell density and greater extracellular matrix were observed in the perfusion groups as compared with the static culture group. In the fluid shear stress group, the cells were larger in size and rougher, and contained a large number of processes (needle-like structures). In some osteoblasts, many tiny synaptic adhesions had extended from the cells in the scaffolds, and the cells were gathered more closely together and were integrated. The cells are arrayed with obvious directionality, according to the direction of PFF. It is possible that following stimulation with PFF, the cells deformed to adapt to the direction of the PFF. These change were used to reduce stress stimulation, maintain physiological function, promote the stress on osteogenesis, and reduce osteoclast activity. With the extended perfusion time, the cells proliferated more actively, cell secretion increased, and the extracellular matrix presented an increasing trend. All of these effects indicated 
that the osteogenesis of osteoblasts was enhanced. This study reveals that a fluid shear stress intensity of $0.8 \mathrm{~Pa}$ has an effect on osteoblasts, conductive to the proliferation and differentiation of osteoblasts within $4 \mathrm{~h}$.

Recently, an important role for $\mathrm{Wnt} / \beta$-catenin signaling has been recognized in promoting bone anabolism. The Wnt family includes more than 15 proteins that have been shown to play an important role in organ development and the homeostasis of several adult tissues, including bone (22). Considerable progress has been made in terms of understanding the role of Wnt/ $\beta$-catenin signaling in osteogenesis and particularly in osteoblast biology; however, little is known about the functions of this pathway in osteocytes (23).

The $\beta$-catenin degradation complex consists of the scaffold proteins, axin and APC, and the protein kinases, casein kinase 1 (CK1) and glycogen synthase kinase 3 (GSK3), thereby relieving $\beta$-catenin (CTNNB1) from its constant phosphorylation by CK1 and GSK3 and its subsequent degradation by the ubiquitin-proteasome pathway $(24,25)$. Hill et al (26) used $\beta$-cat ${ }^{\Delta \text { Prx/- }}$ mice to study the effects of $\beta$-catenin in the limb and head mesenchyme. Their findings revealed that $\beta$-catenin activity is required for the early steps of osteoblast differentiation. On the other hand, stabilization of the $\beta$-catenin function in the mesenchyme of $\beta$-cat $\Delta \mathrm{ex} 3^{\text {Prx/+ }}$ animals suppressed chondrogenesis, rather than stimulating osteoblastogenesis. Day et al (27) demonstrated the similar finding that $\beta$-catenin signaling is required for osteoblasts to complete differentiation and to synthesize properly formed bone.

LRP5 is the most well known member of the LRP family, which constitutes a membrane receptor complex as Wnt ligands. It is a Wnt co-receptor, and Wnt signaling through LRP5 is required for mechanically induced bone formation. Sclerostin is speculated to function as a secreted inhibitor of canonical Wnt/ $\beta$-catenin signaling by binding to LRP5 and LRP6 Wnt co-receptors, preventing their association with the Wnt-Frizzled (Fzd) receptor complex (28-30). Kato et al (31) reported that the germline deletion of murine LRP5 reduced vertebral total bone volume by $40 \%$ at 8 weeks of age when peak bone mass occurred in $\mathrm{LRP}^{+/+}$mice, as determined by histomorphometry. They then disrupted exon 6 of the gene, and also noted that LRP5 ${ }^{--}$mice had tibial fractures by 2 months of age, resulting from low bone mass. Furthermore, when the $\mathrm{LRP5}^{-/-}$mice were only 2 weeks old, the total bone volume was found to be significantly reduced. They also found that the loss of LRP5 did not alter osteoblast apoptosis and differentiation, osteoclastogenesis, or bone resorption. Thus, the deletion of LRP5, by reducing osteoblast proliferation and activity, leads to decreased bone accrual in early post-natal mice.

As shown in a previous study, osteoblast differentiation was arrested at the early progenitor stages, and only type I collagen and ALP were expressed (32). This suggests that $\beta$-catenin signaling is required for osteoblasts to complete differentiation and to synthesize properly formed bone (11). Thus, ALP is known to be an early marker for the osteoblastic phenotype, being upregulated at the onset of differentiation and subsequently decreasing as differentiation progresses (33). In this study, we observed the upregulation of the gene expression of ALP in all PFF groups and the difference was not statistically significant.

Wnt3a initiates canonical Wnt signaling by binding to receptor complexes consisting of LRP5/6 and Frizzled on the cell surface, which results in the nuclear translocation of $\beta$-catenin and the activation of Lef1/Tcf transcription factors (34-36). Thus, we examined whether a canonical Wnt pathway ligand (Wnt3A) that acts through the LRP5 receptor would have similar effects on PFF-induced gene expression. We also observed that $1 \mathrm{~h}$ of PFF followed by $23 \mathrm{~h}$ of incubation without PFF significantly upregulated gene expression.

A great deal of research has indicated that mechanical stress and $\mathrm{Wnt} / \beta$-catenin play important roles in bone formation. The involvement of the $\mathrm{Wnt} / \beta$-catenin pathway in the mechanotransduction of signals from osteocytes has been revealed $(37,38)$. However, studies on mechanical stress and Wnt signaling are limited. In this study, in a 3D cell culture system, loading resulted in the promotion of osteoblast proliferation and differentiation, as well as an increase in the expression of Wnt pathway and $\mathrm{Wnt} / \beta$-catenin target genes. However, there are differences between in vivo and in vitro environments; shear stress needs to be transformed inside the body in future studies.

In conclusion, the results from our study suggest that mechanical stimulation by PFF induces the differentiation, proliferation and apoptosis of osteoblasts and the activation of the $\mathrm{Wnt} / \beta$-catenin signaling pathway in a $3 \mathrm{D}$ cell culture system. The Wnt/Wnt/ $\beta$-catenin signaling pathway is involved in the progression of bone formation. These data provide a framework for understanding the role of the $\mathrm{Wnt} / \beta$-catenin signaling pathway in the mechanical adaptation of bone.

\section{Acknowledgements}

We thank Xiaoyu Li, Yurong Liu, Xiangli Kong and Chaoliang Zhang for their technical assistance. This study was supported by the National Natural Science Foundation for the Youth of China (NSFC) (grant 30801310).

\section{References}

1. Harada S and Rodan GA: Control of osteoblast function and regulation of bone mass. Nature 423: 349-355, 2003.

2. Carter DR, Van der Meulen MC and Beaupre GS: Mechanical factors in bone growth and development. Bone 18 (Suppl 1): 5S-10S, 1996.

3. You J, Yellowley CE, Donahue HJ, Zhang Y, Chen Q and Jacobs CR: Substrate deformation levels associated with routine physical activity are less stimulatory to bone cells relative to loading-induced oscillatory fluid flow. J Biomech Eng 122: 387-393, 2000.

4. Ehrlich PJ and Lanyon LE: Mechanical strain and bone cell function: a review. Osteoporos Int 13: 688-700, 2002.

5. Bodine PVN: Wnt signaling in bone development. In: Bone and Development. Springer, London, pp137-152, 2010.

6. Zhang R, Oyajobi BO, Harris S, Chen D, Tsao C, Deng HW and Zhao M: Wnt/ $\beta$-catenin signaling activates bone morphogenetic protein 2 expression in osteoblasts. Bone 52: 145-156, 2013.

7. Guo Y, Li PF, Shu XC, Deng H, Ma HL and Sun L: Involvement of $\mathrm{Wnt} / \beta$-catenin signaling in the osteogenesis of bone marrow mesenchymal stem cells induced by drynaria total flavonoids. Zhonghua Yi Xue Za Zhi 92: 2288-2291, 2012 (In Chinece).

8. Fischbach C, Kong HJ, Hsiong SX, Evangelista MB, Yuen W and Mooney DJ: Cancer cell angiogenic capability is regulated by 3D culture and integrin engagement. Proc Natl Acad Sci USA 106: 399-404, 2009.

9. Byrne EM, Farrell E, McMahon LA, Haugh MG, O'Brien FJ, Campbel VA, Prendergast PJ and O'Connell BC: Gene expression by marrow stromal cells in a porous collagen-glycosaminoglycan scaffold is affected by pore size and mechanical stimulation. J Mater Sci Mater Med 19: 3455-3463, 2008. 
10. Helmke CD: Factors affecting bone cell growth and differentiation under differing culture conditions. Masters Thesis, Rice University, ETD http://hdl.handle.net/1911/17342, 2000.

11. Jarrahy R, Huang W, Rudkin GH, Lee JM, Ishida K, Berry MD, Sukkarieh M, Wu BM, Yamaguchi DT and Miller TA: Osteogenic differentiation is inhibited and angiogenic expression is enhanced in MC3T3-E1 cells cultured on three-dimensional scaffolds. Am J Physiol Cell Physiol 289: C408-C414, 2005.

12. Barron MJ, Tsai CJ and Donahue SW: Mechanical stimulation mediates gene expression in MC3T3 osteoblastic cells differently in 2D and 3D environments. J Biomech Eng 132: 041005, 2010.

13. Wu YY, Ban Y, Geng N, Wang YY, Liu XG, Yu T and Gong P: Evaluation of different culture techniques of osteoblasts on 3D scaffolds. Cent Eur J Biol 5: 456-465, 2010.

14. Fu Q, Liu YH, Xu YJ, Guo L and Wu CJ: Design and use of flow chamber for fluid shear stress on cells in vitro. Journal of Sun Yat-Sen University: S1, 2009 (In Chinese).

15. Engler AJ, Sen S, Sweeney HL and Discher DE: Matrix elasticity directs stem cell lineage specification. Cell 126: 677-689, 2006.

16. Evans ND, Minelli C, Gentleman E, LaPointe V, Patankar SN Kallivretaki M, Chen X, Roberts CJ and Stevens MM: Substrate stiffness affects early differentiation events in embryonic stem cells. Eur Cell Mater 18: 1-14, 2009.

17. Ghosh K and Ingber DE: Micromechanical control of cell and tissue development: implications for tissue engineering. Adv Drug Deliv Rev 59: 1306-1318, 2007.

18. Karamichos D, Skinner J, Brown R and Mudera V: Matrix stiffness and serum concentration effects matrix remodelling and ECM regulatory genes of human bone marrow stem cells. J Tissue Eng Regen Med 2: 97-105, 2008.

19. Orr AW, Helmke BP, Blackman BR and Schwartz MA Mechanisms of mechanotransduction. Dev Cell 10: 11-20, 2006.

20. Weinbaum S, Cowin SC and Zeng Y: A model for the excitation of osteocytes by mechanical loading-induced bone fluid shear stresses. J Biomech 27: 339-360, 1994.

21. Bakker AD, Soejima K, Klein-Nulend J and Burger EH: The production of nitric oxide and prostaglandin $\mathrm{E} 2$ by primary bone cells is shear stress dependent. J Biomech 34: 671-677, 2001.

22. Riancho JA, Olmos JM, Pineda B, García-Ibarbia C, Pérez-Núñez MI, Nan DN, Velasco J, Cano A, García-Pérez MA, Zarrabeitia MT and González-Macías J: Wnt receptors, bone mass, and fractures: gene-wide association analysis of LRP5 and LRP6 polymorphisms with replication. Eur J Endocrinol 164: $123-131,2011$.

23. Bonewald LF and Johnson ML: Osteocytes, mechanosensing and Wnt signaling. Bone 42: 606-615, 2008.

24. Clevers $H$ and Nusse $R$ : Wnt $/ \beta$-catenin signaling and disease. Cell 149: 1192-1205, 2012.

25. Kobayashi Y, Maeda K and Takahashi N: Roles of Wnt signalingin bone formation and resorption. Jpn Dent Sci Rev 44: $76-82,2008$
26. Hill TP, Später D, Taketo MM, Birchmeier W and Hartmann C: Canonical Wnt/beta-catenin signaling prevents osteoblasts from differentiating into chondrocytes. Dev Cell 8: 727-738, 2005.

27. Day TF, Guo X, Garrett-Beal L and Yang Y: Wnt/ $\beta$-catenin signaling in mesenchymal progenitors controls osteoblast and chondrocyte differentiation during vertebrate skeletogenesis. Dev Cell 8: 739-750, 2005.

28. Tüysüz B, Bursalı A, AlpZ, Suyugül N, Laine CM and Mäkitie O: Osteoporosis-pseudoglioma syndrome: three novel mutations in the LRP5 gene and response to bisphosphonate treatment. Horm Res Paediatr 77: 115-120, 2012.

29. Wodarz A and Nusse R: Mechanisms of Wnt signaling in development. Annu Rev Cell Dev Biol 14: 59-88, 1998.

30. Johnson ML and Kamel MA: The Wnt signaling pathway and bone metabolism. Curr Opin Rheumatol 19: 376-382, 2007.

31. Kato M1, Patel MS, Levasseur R, Lobov I, Chang BH, Glass DA II Hartmann C, Li L, Hwang TH, Brayton CF, Lang RA, Karsenty G and Chan L: Cbfa1-independent decrease in osteoblast proliferation, osteopenia, and persistent embryonic eye vascularization in mice deficient in Lrp5, a Wnt coreceptor. J Cell Biol 157: 303-314, 2002.

32. Owen TA, Aronow M, Shalhoub V, et al: Progressive development of the rat osteoblast phenotype in vitro: reciprocal relationships in expression of genes associated with osteoblast proliferation and differentiation during formation of the bone extracellular matrix. J Cell Physiol 143: 420-430, 1990.

33. Rawadi G, Vayssière B, Dunn F, Baron R and Roman-Roman S: BMP-2 controls alkaline phosphatase expression and osteoblast mineralization by a Wnt autocrine loop. J Bone Miner Res 18 1842-1853, 2003.

34. Olivares-Navarrete R, Hyzy SL, Hutton DL, Dunn GR, Appert C, Boyan BD and Schwartz Z: Role of non-canonical Wnt signaling enhances osteoblast maturation on microstructured titanium surfaces. Acta Biomater 7: 2740-2750, 2011

35. Jullien N, Maudinet A, Leloutre B, Ringe J, Häupl T and Marie PJ: Downregulation of ErbB3 by Wnt3a contributes to wnt-induced osteoblast differentiation in mesenchymal cells. J Cell Biochem 113: 2047-2056, 2012

36. Natsume H, Tokuda H, Matsushima-Nishiwaki R, Kato K, Yamakawa K, Otsuka T and Kozawa O: Wnt3a upregulates transforming growth factor- $\beta$-stimulated VEGF synthesis in osteoblasts. Cell Biochem Funct 29: 371-377, 2011.

37. Sakai A: Space flight/bedrest immobilization and bone. Osteocyte as a sensor of mechanical stress and Wnt signal. Clin Calcium 22: 1829-1835, 2012 (In Japanese).

38. Sakai A: Mechanical stress and Wnt signal. Clin Calcium 23: 839-845, 2013 (In Japanese). 